\title{
Coagulation Profile in Hepatobiliary Disorders Affected Dogs
}

\author{
K. Lakshmi* , K. Padmaja, P. Nagaraj, A. Gopala Reddy and M. Gnana Prakash \\ Department of Veterinary Medicine, College of Veterinary Science, \\ Rajendranagar, Hyderabad-30, Telangana, India \\ *Corresponding author
}

\begin{tabular}{|c|c|}
\hline & A B S T R A C T \\
\hline Keywords & \multirow{3}{*}{$\begin{array}{l}\text { Coagulation parameters in } 140 \text { dogs affected with hepatobiliary studies } \\
\text { were studied. The mean platelet count }(10 \% / \mu \mathrm{L}) \text {, prothrombin time (sec) and } \\
\text { activated partial thromboplastin time (sec) in healthy control, diffuse } \\
\text { parenchymal disorders with ascites, without ascites, focal parenchymal } \\
\text { disorders and biliary tract disorders affected dogs were } 3.27 \pm 0.13 \text {, } \\
1.87 \pm 0.07,1.92 \pm 0.08,1.43 \pm 0.14 \text { and } 1.88 \pm 0.06 \times 10^{5} / \mu \mathrm{L} ; 8.67 \pm 0.33 \text {, } \\
10.60 \pm 0.21,11.63 \pm 0.31,9.84 \pm 0.30 \text { and } 9.86 \pm 0.09 \text { seconds; and } 20.22 \pm \\
2.32,34.41 \pm 1.44,31.88 \pm 2.03,28.42 \pm 1.32 \text { and } 32.28 \pm 1.15 \text { seconds, } \\
\text { respectively. }\end{array}$} \\
\hline Article Info & \\
\hline $\begin{array}{l}\text { Accepted: } \\
\text { 28 September } 2017 \\
\text { Available Online: } \\
10 \text { November } 2017\end{array}$ & \\
\hline
\end{tabular}

\section{Introduction}

Coagulopathies in chronic hepatobiliary disorders may develop as a result of hepatic synthetic failure, vitamin $\mathrm{K}$ deficiency in cholestasis or from qualitative or quantitative platelet defects. Low grade disseminated intravascular coagulation common in patients with hepatic insufficiency, may also contribute to bleeding tendencies (Webster and Centre, 1995). Dogs with acute liver disease and chronic hepatitis, estimation of coagulation parameters has prognostic significance in both human and veterinary patients (Shih et al., 2007). Usually, one or more coagulation abnormalities can be encountered with the dogs affected with hepatic disease and suggest that the coagulation changes may represent hepatic synthetic failure. Estimation of coagulation profile viz., prothrombin time, activated partial thromboplastin time and platelet count are the important screening tests to be performed before undertaking tissue core biopsy procedures (Geschen, 2009).

\section{Materials and Methods}

The present study was conducted on 140 dogs that were presented to Veterinary Hospital, Bhoiguda with the signs suggestive of hepatobiliary disorders. Blood samples were collected from the peripheral (cephalic/saphenous) veins of dogs suffering with hepatobiliary disorders in dogs using sterile vaccutainer containing EDTA (ethylene di amine tetra acetic acid-2 $\mathrm{mg} / \mathrm{ml}$ blood), for estimation of platelet count on 
Horiba Medical ABX Micros ESV 60 and also into the sterile vaccutainer containing tri sodium citrate $(3.2 \%)$. Collected tri sodium citrated blood was mixed gently and plasma was harvested by centrifugation at $3000 \mathrm{rpm}$ for 15 minutes. Prothrombin time (PT) and Activated partial thromboplastin time (aPTT) were estimated from the harvested plasma by using $\mathrm{mispa} / \mathrm{clog}$ opto-mechanical coagulation analyzer which applies turbo densitometric measuring principle manufactured by Agappe diagnostics Pvt Ltd as suggested by Sumathi et al., (2015). Further, blood and plasma was collected from apparently healthy dogs to obtain normal values.

\section{Results and Discussion}

In the present study, the mean levels of platelet counts in dogs with diffuse parenchymal disorders with ascites, without ascites, focal parenchymal disorders and biliary tract disorders were $1.87 \pm 0.07$, $1.92 \pm 0.08, \quad 1.43 \pm 0.14$ and $1.88 \pm 0.06 \mathrm{x}$ $105 / \mu \mathrm{L}$, respectively. There was a significant decrease $(\mathrm{P}<0.01)$ in platelet count in all the dogs of hepatobiliary disorders as compared with healthy control (3.27 \pm 0.13 $\left.\mathrm{x} 10^{5} / \mu \mathrm{L}\right)$.Similar findings were reported by Prins et al., (2010) and Tantary et al., (2014), who recorded reduced platelet levels in chronic hepatitis or cirrhosis and hepatobiliary disorders affected dogs. These findings are in agreement with Brovida and Rothuizen (2008), who stated that qualitative and quantitative platelet defects accompany hepatobiliary diseases in dogs. Several mechanisms have been suggested for thrombocytopenia in patients with liver diseases, which include increased platelet sequestration in the spleen as a result of congestive spleenomegaly, reduced production of thrombopoietin by the liver, increased platelet breakdown due to auto antibodies and increased consumption resulting from low grade disseminated intravascular coagulopathy (Prins et al., 2010).

The mean levels of prothrombin time (PT) in dogs with diffuse parenchymal disorders with ascites, without ascites, focal parenchymal disorders and biliary tract disorders were $10.60 \pm 0.21,11.63 \pm 0.31,9.84 \pm 0.30$ and $9.86 \pm 0.09$ seconds, respectively. Significant increase $(\mathrm{P}<0.01)$ in diffuse parenchymal disorders with ascites, without ascites and biliary tract disorders, while it was significant at $5 \% \quad(\mathrm{P}<0.05)$ in focal parenchymal disorders as compared with healthy control (8.67 \pm 0.03 seconds) was observed. These findings are in accordance with Shih et al., (2007) and Elhiblu et al., (2015), who observed prolonged prothrombin time (PT) in dogs affected with chronic hepatitis, and liver cirrhosis, respectively. The more commonly seen combination of prolonged PT and aPTT was caused by deficiency of multiple plasma coagulation factors, or less likely a common pathway factor deficiency i,e., F X, FII, Fibrinogen (Callan, 2013).

Table.1 Mean values of coagulation parameters in healthy and hepatobiliary disorders in dogs

\begin{tabular}{|c|c|c|c|c|c|c|}
\hline & Parameter & $\begin{array}{c}\text { Healthy } \\
\text { control } \\
(\mathbf{n = 1 0})\end{array}$ & $\begin{array}{c}\text { Diffuse } \\
\text { parenchymal } \\
\text { disorders with } \\
\text { ascites (n= 32) }\end{array}$ & $\begin{array}{c}\text { Diffuse } \\
\text { parenchymal } \\
\text { disorders without } \\
\text { ascites (n= 32) }\end{array}$ & $\begin{array}{c}\text { Focal } \\
\text { parenchymal } \\
\text { disorders } \\
(\mathbf{n}=\mathbf{2 4})\end{array}$ & $\begin{array}{c}\text { Biliary Tract } \\
\text { disorders } \\
(\mathbf{n}=\mathbf{5 2})\end{array}$ \\
\hline 1 & Platelet count $\left(10^{5} / \mu \mathrm{L}\right)$ & $3.27 \pm 0.13$ & $1.87 \pm 0.07^{* *}$ & $1.92 \pm 0.08^{* *}$ & $1.43 \pm 0.14^{* *}$ & $1.88 \pm 0.06^{* *}$ \\
\hline 2 & Prothrombin Time (Sec) & $8.67 \pm 0.03$ & $10.60 \pm 0.21^{* *}$ & $11.63 \pm 0.31^{* *}$ & $9.84 \pm 0.30^{*}$ & $9.86 \pm 0.09^{* *}$ \\
\hline 3. & $\begin{array}{c}\text { Activated partial } \\
\text { thromboplastin time (Sec) }\end{array}$ & $20.22 \pm 2.32$ & $31.88 \pm 2.03^{* *}$ & $28.42 \pm 1.32^{* *}$ & $32.28 \pm 1.15^{* *}$ \\
\hline
\end{tabular}

Significant at $(\mathrm{P}<0.05),{ }^{*}$ Significant at $(\mathrm{P}<0.01)$ 
The mean levels of activated partial thromboplastin time (aPTT) in dogs with diffuse parenchymal disorders with ascites, without ascites, focal parenchymal disorders and biliary tract disorders were $34.41 \pm 1.44,31.88 \pm 2.03$, $28.42 \pm 1.32$ and $32.28 \pm 1.15$ seconds, respectively. Increased levels were significant $(\mathrm{P}<0.01)$ in all the dogs of hepatobiliary disorders as compared to the apparently healthy control group $(20.22 \pm 2.32$ seconds). These findings were in accordance with Shih et al., (2007), Penny and Watson (2008), Prins et al., (2010) and Elhiblu et al., (2015), who observed prolonged activated partial thromboplastin time (aPTT) in dogs affected with chronic hepatitis, parenchymal hepatic diseases, hepatic disorders and liver cirrhosis, respectively. Prolongations of PT and a PTT carry a prognostic significance suggestive of coagulation changes representing hepatic synthetic failure (Amsellem, 2006) and predict shorter survival times (Shih et al., 2007). Thrombocytopenia and prolonged PT and aPTT would be suggestive of consumptive coagulopathy, as potentially noted in patients with severe hemorrhage or disseminated intravascular coagulation (Webster and Centre, 1995). The results are presented in table 1 .

Significantly decreased platelet counts and prolonged prothrombin time and activated partial tromboplastin time were the coagulation abnormalities recorded in all dogs affected with hepatobiliary disorders.

\section{References}

Amsellem, P. M., Seim, H.B and Mac Phail, C. M. 2006. Long term survival and risk factors associated with biliary surgery in dogs: 34 cases (1999-2004). Journal of American Veterinary Medical Association, 229(9): 1451-1457.

Brovida, S. and Rothuizen, J. 2008. Liver and pancreatic diseases. In: Ettinger, $S$ J.and Feldman, EC (eds). Text book of Veterinary Internal Medicine. $7^{\text {th }}$ edn. Elsevier
Saunders Co., St Lois: Pp. 1609-1690.

Callan, 2013. Coagulopathy. In Washabau $R J$ and Day $M J$. Text book of canine and feline gasteroenterology, Chapter 9. Elsevier publishers. Pp. 87-92.

Elhiblu, M. A., Dua, K., Mohindroo, J., Mahajan, S. K., Sood, N. K., Dhaliwal, P. S. 2015. Clinico - haemato biochemical profile of dogs with liver cirrhosis. Veterinary World 8(4): 487-491.

Geschen, L. 2009.Update on hepatobiliary imaging. Small Animal Practice, 39: 439467.

Penny and Watson. 2008. Clinical manifestations of hepatobiliary disease. Chapter 35, part 4. In: Small animal Internal Medicine by Richard W. Nelson and C. Guillermo Counto. Fourth edition. Elsevier Publishers, Pp. 485-519.

Prins, M., Schellens, C. J. M. M., Van leeuwen, M. W., Rothuizen, J., Teske, E. 2010. Coagulation disorders in dogs with hepatic disease. The Veterinary Journal 185: pp; 163-168.

Shih, J. L., Keating, J.H., Freeman, L. M. and Webster, C. R. L. 2007. Chronic hepatitis in Labrador Retrievers, clinical presentation and prognostic factors. Journal of Veterinary International. Medicine. 21: 33-39.

Sumathi, D., Vibin, V., Nambi, A. P., Joseph, C., Baby,K, R. 2015.Hemostatic profile of bitches with pyometra. Intas polivet, 16(1): 150-152.

Tantary, H. A., Soodan, J. S., Chirag,S., Ansari, M. M., Kumar, S. and Imtiyaz, T. 2014. Diagnostic studies in dogs with hepatic disorders. International Journal of Veterinary Science 3(4): 210-215.

Webster, C.R. L. and Centre. 1995. Chronic hepatitis: Therapeutic considerations. In Text book of Kirks current therapy XII Small animal practice by Bonagura J D and Kirk R.W., W.B. Saunders company, Philadelphia, Pp. 749-756.

\section{How to cite this article:}

Lakshmi, K., K. Padmaja, P. Nagaraj, A. Gopala Reddy and Gnana Prakash, M. 2017. Coagulation Profile in Hepatobiliary Disorders Affected Dogs. Int.J.Curr.Microbiol.App.Sci. 6(11): 3975-3977. doi: https://doi.org/10.20546/ijcmas.2017.611.465 